\title{
Feasibility Study for Distribution of Zakat to Mustahiq Community in West Bandung: A Village Assisted by Rumah Zakat
}

\author{
Elis Nurhasanah \\ Department of Middle East and Islamic Studies \\ Universitas Indonesia Depok, \\ Indonesia \\ elisnurhasanah93@gmail.com
}

\author{
Mohamad Soleh Nurzaman \\ Department of Islamic Economics \\ Universitas Indonesia \\ Depok, Indonesia \\ dedenmsn@gmail.com
}

\author{
Yusuf Wibisono Department of \\ Islamic Economics Faculty of \\ Economics and Business \\ Universitas Indonesia \\ Depok, Indonesia \\ wibisono16@gmail.com
}

\begin{abstract}
This paper assessed the feasibility of communitybased zakat recipients and recommended relevant programs to alleviate mustahiq community conditions in West Bandung District. Research on feasibility studies for community-based zakat programs is still infrequent. Furthermore, no standardized assessment tool has been designed to measure the feasibility of becoming a zakat recipient based on characteristics of the community. Therefore, this study used the Village Zakat Index (IDZ) instrument adopted from Puskas BAZNAS. IDZ was derived from the average calculation of five dimensions of economics, health, education, social and humanity, and da'wah in the community by using a mixed methods approach and multistage cluster sampling. Results showed that Mekarwangi Village in West Bandung District could be helped by the charity fund based on calculation of IDZ that reached 0.59. Meanwhile, the detailed index of each dimension's economic conditions was 0.32 ; the educational and health were 0.64 and 0.52 respectively. Dimension of Social and humanity was 0.71 and 0.80 for the da'wah dimension. Based on these results, the program relevant to the condition of the mustahiq community in West Bandung District Mekarwangi Village was community economic improvement through empowerment of economic potential.
\end{abstract}

Keywords - utilization of zakat, mustahiq community, zakat village index

\section{INTRODUCTION}

The percentage of poverty in West Java, especially in the province's rural areas is above Indonesia's general percentage of rural poverty. In 2017 , it was $11.26 \%$, greater than in Indonesia as a whole $(10.38 \%)$. In contrast, the percentage was $7.14 \%$ in urban areas, a difference of $4.12 \%$. But 2017 differed little from the previous 5 years in that West Java's rural poverty has been ongoing. Although in 2017 , the poverty rate declined by $0.5 \%$ from the previous year, this statistic was not significant because it was still fluctuating (Fig. 1).
The West Bandung District has a percentage of poverty above even the average of West Java, that is, $11.71 \%$, compared to $8.95 \%$. Furthermore, conditions there are vulnerable to increasing poverty, as fluctuations during the last 5 years show. Fig. 2 displays the percentage of poverty in West Bandung District for the last 5 years based on figures from West Java's Central Statistics Agency.

Certainly, the West Bandung District requires solutions to alleviate rural poverty. First, poverty is a crucial problem for developing countries, and the government is obligated to provide equal rights for both urban and rural residents in avoiding poverty and achieving prosperity. In relation to this, (Sadeq, 2002) defines poverty as an affront to human rights that include basic rights to food, clothing, protection, education and employment [1].

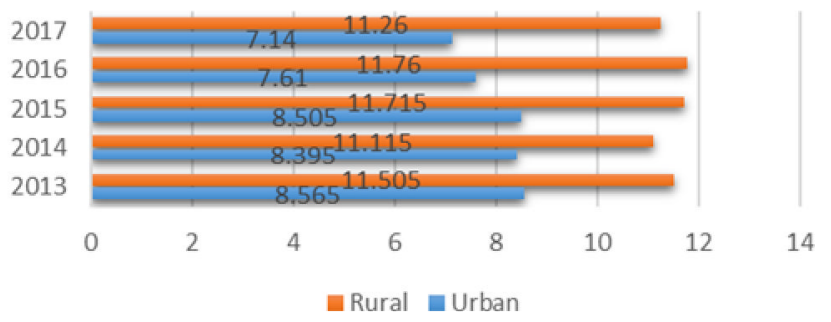

Fig. 1. Percentage of rural and urban poverty in west java province

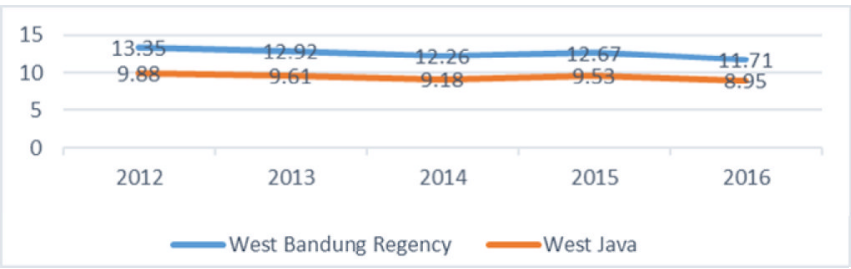

Fig. 2. Percentage of poverty rate in west bandung district in 2012-2016

Poverty occurs not only because of low income, but because of three categories of poverty phenomena: 
- Low income

- Non-income factors such as poor health and a low level of literacy

- Lack of access to opportunities such as health facilities, sources of income, and employment

According to Hassan, et al. [2], Islam defines poverty as a status in which individuals fail to fulfill one of the purposes of the law (maqasid al shariah), namely hifz al-din (protection of faith), hifz al-nafs (protection of human life), hifz al-'aql (protection of intellect), hifz al-nasl (protection of posterity), and hifz al maal (protection of wealth) [2]. Moreover, Al-Ghazali divides poverty into two parts: first, poverty in relation to material needs and, second, poverty in relation to spiritual needs.

Islam has several strategies for reducing poverty, specifically actions that are positive, preventive, and corrective. Too, Islam employs various positive steps to reduce poverty through income growth, functional income distribution, and equal opportunities. Income growth emphasizes individual consumption behavior and halal income. In the distribution of functional income, Islam employs equitable distribution rather than income among factors of production such as the principle of profit sharing (mudaraba), while its preventive action is regulating ownership and preventing malpractice. Furthermore, Islam's corrective action involves reducing poverty by encouraging transfer of wealth so that it is not concentrated among the rich. This action is conducted through: (a) zakat, (b) social funds (sadaqah/infaq), and (c) state responsibility (enforcement and basic needs) [2].

One social instrument that serves to reduce poverty and ensure welfare is zakat. According to Sadeq [1], Islam's several poverty alleviation instruments can be divided into three parts:

1) Compulsory charity is zakat and fitrah.

2) Optional charity is infaq and sadaqah.

3) Eternal charity is waqf.

Zakat is included in compulsory charity because it is the third pillar of Islam - the hadith from Turmuzi and Muslim in the third hadith Arba'in Nawawi (2001), and Quran Al Tauba ayah 103. Zakat is an Islamic economic concept with a role in ensuring the welfare of the people. According to Beik [3], zakat is an economic institution capable of reducing the number and percentage of poor families and the depth and severity of poverty [4]. That zakat can ensure the welfare of the people was reflected during the caliphate of Umar bin Abdul Aziz.

Studies that support the role of zakat include the research of Febianto and Ashany [5]. Both state that zakat funds and other social funds gathered through the qardul hasan scheme can improve economic empowerment. Next, the research of Nurwenda and Mulyaningsih [6] stated that utilization of productive zakat can create social entrepreneurs and become a tool for improving life and business performance. Both these studies showed positive results in utilization of productive zakat funds for improving recipients' welfare. Beik and Arsyianti's [7] study "Measuring Zakat Impact on

Poverty and Welfare Using the CIBEST Model" in the National Board of Zakat (BAZNAS) Jakarta district and Dompet Dhuafa demonstrates zakat's significant impact. The study obtained an increased spiritual score of $13.09 \%$, so that the welfare index could be increased by $96.8 \%$, the material poverty index could be lowered by $30.15 \%$, and the absolute poverty index could be decreased by $91.30 \%$. Nurzaman [8] conducted a study on zakat's role by comparing households receiving and not receiving zakat funds. Results showed that mustahiq households had a higher Human Development Index than non-mustahiq households. This means that zakat can increase the income, health, and education of its recipients (mustahiq).

Through the mustahiq community-based zakat program, zakat can be an empowering solution to village poverty. This means the community-based zakat target is poor villages, or the mustahiq community is village-based. Utilization of village-based zakat is expected to provide a multiplier effect for national welfare. However, community-based zakat programs should assess the feasibility of a village participating in a community-based zakat program to discover which programs are needed to improve their welfare.

Community-based zakat programs or Zakat Community Development (ZCD) by BAZNAS and Integrated Community Development (ICD) by Rumah Zakat become the focus of the zakat utilization program. West Bandung District is one area in West Java that became a recipient of the ICD program and one village is Mekarwangi. Using measurements to identify whether Mekarwangi Village is still worth being assisted by the zakat fund is important, and if that assistance is feasible, what program is relevant to its conditions.

\section{LITERATURE REVIEW}

\section{A. Feasibility Study}

A feasibility A feasibility study is an analysis of an idea. Concentration on a feasibility study answers the important question "Should we proceed with the proposed project idea?" Here, all research activities are directed to help answer this question. A feasibility study can be used in many ways but mainly focuses on the proposed business venture. According to Claase [9], three main commonalities define feasibility studies throughout various fields: Feasibility studies (1) are performed before beginning an endeavor; (2) are designed to answer the "Go/No Go" question (whether or not to proceed with an endeavor); and (3) provide insight in the probable success or failure of a prospective endeavor. Jebrin (2017) defined the feasibility study as a tool that can provide a technical, economic, and financial justification of a decision to finance an investment project. The feasibility study is a critical step in the business assessment process because it aims to provide decision makers with comprehensive project-specific information to decide whether the project's economic returns are likely to be worthwhile (Jebrin, 2017:3).

Zawde [10] in Jebrin (2017:4) described the following general purposes of feasibility studies:

- Describing the need for the project

- Identifying where management wants to go

- How the project will be accomplished

- Resources needed for the project

- Assistants or helpers in the project

- Target date for project accomplishment

- Cost of the project

- Benefits of the project

- Risks involved in the project

- Alternative solutions for the problem

- Crucial issues that prevent the project from being successful in the marketplace 
Thus, the feasibility study is an analytical tool for measuring the condition that the program attempts to alleviate, what problems occur, and what solutions are needed.

\section{B. Utilization of Zakat}

Utilization of zakat in Zakat Act No. 02, 2014, article 1, paragraph 5 is distribution of zakat for productive business (empowerment) in the context of addressing poverty and improving people's quality of life. Law No. 23, 2011, on Management of Zakat states that:

- Zakat can be utilized for productive efforts in handling the poor and improving the quality of people's lives (article 1, paragraph 5, of Act No. 02, 2014).

- Utilization of zakat for productive business is executed if the basic necessities of mustahiq have been fulfilled.

Utilization of zakat is divided into two, consumptive and productive purposes. Consumptive purpose is direct provision of funds as compensation to meet recipients' (mustahiq) needs. According to the Ministry of Religious Affairs of the Republic of Indonesia, Directorate General of Islamic Community Guidance, and the Haj Administration Directorate of Development of Zakat and the Waqf Development Directorate, there are several requirements for consumptive utilization of zakat funds, some of which follow:

1) Results of data collection and research on mustahiq's eight ashnaf (types of people), especially the poor

2) Preference of the most powerless and needy, to meet their basic economic requirements

3) Preferably for mustahiq in their respective territories, distribution of zakat funds is temporary relief for solving urgent needs.

Utilization of zakat for consumptive purpose is given to an individual-based asnaf. Added to the consumptive purpose is utilization of zakat for the productive purpose, that is, provision of revolving funds, which are empowerment assistance accomplished through a continuous program. This opens the opportunity for additional funding chances. The main aim is to establish a mustahiq's economic independence and prosperity. Utilization of productive zakat makes the community or society a mustahiq community.

Previous to utilization of community-based zakat, a study should be conducted on the community's potential to become mustahiq. Thus, with evaluation of the potential or strength of a community, mustahiq will be more focused because the community's process of adaptation is known. Too, utilization of zakat for the productive purpose has a multiplier effect in the country's economy. The community-based zakat empowerment program is expected to develop existing potential and empower the community.

\section{Mustahiq Community}

Mustahiq is a group of beneficiaries of zakat (asnaf) who have a right to receive zakat. Asnaf is the target of redistribution prescribed in the Holy Al-Quran surah alTaubah, verse 60 . The verse describes eight types of people who have a right to receive zakat: (i) poor (fakir), (ii) indigent (Miskin), (iii) Amil, (iv) Muallaf, (v) Riqab, (vi) Gharimin, (vii) Fisabilillah, and (viii) Ibnussabil. Stoner and Sirait (1993) define communities as a collection of two or more people who interact, frequently to achieve a common goal, also frequently through community development. The mustahiq community is a group of people who receive benefits of zakat funds or community-based zakat. Community-based zakat in BAZNAS terminology is known as ZCD. ZCD integrates several programs to address health, economic, educational, and social issues with social funds, namely zakat, infaq, and alms addressed to the community.

The ZCD program takes different approaches: the community approach and the geographical/regional approach. The community approach involves the community or an organized group mustahiq with the same activities. The geographical or regional approach uses location as the target based on geographical problems, population, and the program target area based on the society's condition, whether urban, rural, mountain, or coastal.

The main, but interrelated element in the ZCD program is called community "Caturdaya." The content of community "Caturdaya Masyarakat" is empowerment in education, health, economics, and religious life. In the ZCD program, the community can be categorized as prosperous and independent if it meets "the Caturdaya Masyarakat."

\section{Zakat Village Index}

The Zakat Village Index is an instrument adopted from Puskas BAZNAS as a tool to assess feasibility for receiving charity and for monitoring and evaluating a communitybased zakat program [11]. In general, the Zakat Village Index has five dimensions: economic, educational, health, social and humanity, and $d a$ 'wah. Differences between the Zakat Village Index and other indexes, such as the Village Build Index, are elements of religiosity as part of the assessment. The fifth dimension of the Zakat Village Index, $d a$ 'wah, has several variables and indicators for determining the Zakat Village Index's outcome (Table I).

\section{METHOD}

\section{A. Data and Sampling}

For this mixed-method study, sources of data were primary and secondary. Primary data was obtained through direct interviews using a questionnaire. Secondary data was obtained through a literature review from journals, books, archival/document websites, and other literature. The sample population was West Bandung villagers.

The multistage cluster sampling method was used, that is, a two-stage or more technique in determining sampling by special consideration [12]. Stages for determining this study's sampling were as follows: 1) Conducting selection of several villages assisted by Rumah Zakat to be sampled and represent other villages in the West Bandung District, specifically, Ngamprah, Sirnajaya, Rajamandala Kulon, Gudangkahuripan, and Mekarwangi Villages; 2) in the second stage, one village was selected, Mekarwangi Village.

\section{B. Estimation Techniques}

This research used the Zakat Village Index, an instrument adapted from the Center for Strategic Studies, the National Board of Zakat (Puskas BAZNAS). Interviews were conducted at the village office, while the RT questionnaire was completed so that the researcher only confirmed the questionnaire.

The Zakat Village Index (IDZ) has five components for measuring charity's effectiveness in the welfare of the community: the economic dimension, educational dimension, 
health dimension, social dimension of humanity, and dimension of $d a$ 'wah. The economic dimension consists of four variables: presence of productive economic activities, trade centers, access to transportation and logistics services, and access to financial institutions.

Dimensions of health have three such variables: public health, health services, and health insurance. Educational dimensions are obtained from levels of education and literacy and the presence of community education facilities. Social and human dimensions are measured by availability of interaction space, electrical infrastructure, communication and information, and disaster mitigation.

The da'wah dimension derives from assessment means, religious companions, level of society's religious knowledge, and the level of religious activity and community participation. If the IDZ value approaches 1 , then the village is increasingly not prioritized for assistance, but if the IDZ value approaches 0 , it is prioritized for assistance.

Beik et al. [11] determined some procedures in calculation of the Zakat Village Index, first, assessment criteria of each indicator using a 5-point Likert scale. As in Table II, the higher the village's index value, the less the village is prioritized for help. This means the condition of the village is very good. Conversely, the lower the village's index value, the more the village is prioritized for help. Having obtained actual figures (based on facts, findings, and data obtained), researchers calculate the indicator with the following:

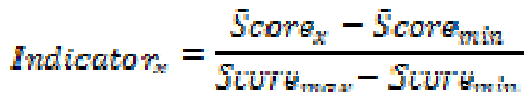

Second, after obtaining an indicator value, researchers then multiply by the indicator's weighted value to obtain the indicator index. Next, index indicators are grouped according to the indicator of variables, and fourth, multiplied by the weight of each indicator variable to obtain the value of the variable's index. Fifth, the index of variables obtained is then multiplied by the weight of each dimension to obtain the dimension index. The result is a composite index of the Zakat Village Index. The formula is as follows (Table II):

$$
Z V I=\frac{X 1_{e c}+X 2_{\text {has }}+X 3_{g d c}+X 4_{s o c}+X 5_{d a}}{5}
$$

TABLE II. SCORE RANGE OF THE ZAKAT VILLAGE INDEX (IDZ)

\begin{tabular}{|l|l|l|}
\hline \multicolumn{1}{|c|}{ Score Range } & Information & \multicolumn{1}{|c|}{ Interpretation } \\
\hline $0.00-0.20$ & Very Low & $\begin{array}{l}\text { Highly prioritized for } \\
\text { assistance }\end{array}$ \\
\hline $0.21-0,40$ & Low & Prioritized for assistance \\
\hline $0.41-0.60$ & Medium & $\begin{array}{l}\text { Can be considered for } \\
\text { assistance }\end{array}$ \\
\hline $0.61-0.80$ & Good & $\begin{array}{l}\text { Less priority for } \\
\text { assistance }\end{array}$ \\
\hline $0.81-1.00$ & Excellent & $\begin{array}{l}\text { Not prioritized for } \\
\text { assistance }\end{array}$ \\
\hline
\end{tabular}

The estimation technique for calculating IDZ value uses the Multistage Weighted Index method, which allows calculation not only of the final (composite) index value, but also the index value for each component. The index value ranges from 0 to 1 . If the IDZ value approaches 1 , then the village should not be prioritized for assistance by the zakat community program. Conversely, if the index value approaches 0 , the village should be prioritized for assistance [11].

\section{RESULT AND DISCUSSION}

The result of the Zakat Village Index for Mekarwangi Village shows that it can be considered for assistance. The value obtained was 0.59 , derived from the index values of economic, health, education, social and human, and $d a$ 'wah dimensions. The index variable was obtained from the indicator index of variables within each dimension's indicators. More details are in Figs. 3.

Mekarwangi Village's economic dimension, 0.32 , shows that its economic condition is inadequate, thus prioritizing it for assistance. Mekarwangi Village's economic condition is influenced by its population's low productive economic activity at 0.26 points. Yet from another viewpoint, Mekarwangi Village has great potential in agriculture, possibly as a plantation. However, small and medium enterprises in Mekarwangi Village have been unable to compete. Lack of a village trade center has affected Mekarwangi Village's economic condition, scored at 0.24. More details are in table III.

Mekarwangi Village's health dimension is higher than its economic dimension, but it can still be considered for assistance with a score of 0.52 . However, in this case, zakat management institutions may reconsider distribution of zakat funds to health programs. The village's health indices are supported by a clean water facility provided by BUMDES (Village Owned Enterprise), and the majority of its houses are livable and permanent.

As shown in Table IV, the lowest score of health dimension variables is ownership of health insurance. The number of villagers with BPJS is approximately $13.16 \%$. Health services owned by Mekarwangi Village are a village delivery cottage, nine integrated service posts, and 11 village midwives with a healthy care variable score of 0.38 (Table IV).

Dimensions of education are influenced by the level of education and literacy and by the presence or absence of educational facilities. Of Mekarwangi Village's total population, the number of educated residents is only 483 high school seniors. However, as many as 4,318 villagers aged 15 to 45 can read and count, with the indicator value of index 1 , so as to produce a variable index of 0.52 (Table V).

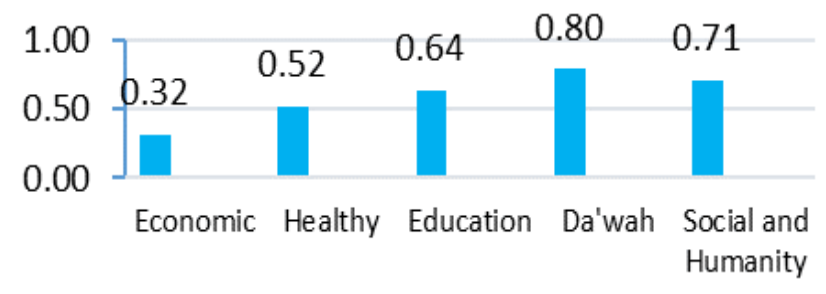

Figs. 3. ZVI Summary Result 
TABLE III. RESULTS FOR ECONOMIC DIMENSION

\begin{tabular}{|c|c|c|c|c|}
\hline $\begin{array}{c}\text { Dimension } \\
\text { Index }\end{array}$ & Variables & $\begin{array}{c}\text { Variable } \\
\text { Index }\end{array}$ & Indicators & Indicator Index \\
\hline \multirow{11}{*}{0.32} & \multirow{3}{*}{$\begin{array}{l}\text { Productive } \\
\text { Economic Activity }\end{array}$} & \multirow{3}{*}{0.26} & $\begin{array}{l}\text { Availability of diversified main } \\
\text { product/production center }\end{array}$ & 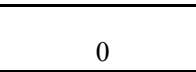 \\
\hline & & & Labor Force Participation Rate & 0.75 \\
\hline & & & $\begin{array}{l}\text { Availability of Creative } \\
\text { Industries Community }\end{array}$ & 0.00 \\
\hline & \multirow{2}{*}{$\begin{array}{l}\text { Village Trade } \\
\text { Center }\end{array}$} & \multirow{2}{*}{0.24} & Market & 0.00 \\
\hline & & & Trade Center & 0.50 \\
\hline & \multirow{3}{*}{$\begin{array}{l}\text { Transportation } \\
\text { Acsess and } \\
\text { Logistics/ } \\
\text { Shipping Services }\end{array}$} & \multirow{3}{*}{0.42} & Accessibility of Village Road & 1.00 \\
\hline & & & Public Transport Mode & 0.00 \\
\hline & & & $\begin{array}{ll}\text { Logistics } & \text { Services/Freight } \\
\text { Forwarding } & \end{array}$ & 0.00 \\
\hline & \multirow{3}{*}{$\begin{array}{l}\text { Access to } \\
\text { Financial } \\
\text { Institutions }\end{array}$} & \multirow{3}{*}{0.38} & $\begin{array}{l}\text { Availability and accessibility of } \\
\text { sharia and conventional } \\
\text { financial institutions }\end{array}$ & 0.00 \\
\hline & & & $\begin{array}{l}\text { Community engagementin loan } \\
\text { shark (rentenir) }\end{array}$ & 1 \\
\hline & & & $\begin{array}{lll}\begin{array}{l}\text { Engagement } \\
\text { institution }\end{array} & \text { in financial }\end{array}$ & 0.25 \\
\hline
\end{tabular}

TABLE IV. RESUlTS FOR HEALTH DIMENSION

\begin{tabular}{|c|c|c|c|c|}
\hline Dimension Index & Variable & $\begin{array}{l}\text { Variable } \\
\text { Index }\end{array}$ & Indicatord & Indicator Index \\
\hline \multirow{10}{*}{0.52} & \multirow{4}{*}{ Public health } & \multirow{4}{*}{0.94} & Clean Water Facilities & 1.00 \\
\hline & & & $\begin{array}{l}\text { Number of Houses with } \\
\text { Bathrooms and Toilets }\end{array}$ & 0.75 \\
\hline & & & $\begin{array}{l}\text { Number of Houses } \\
\text { Drinking Water }\end{array}$ & 1.00 \\
\hline & & & $\begin{array}{l}\text { Condition of House of } \\
\text { Residents }\end{array}$ & 1.00 \\
\hline & \multirow{5}{*}{ Health Services } & \multirow{5}{*}{0.38} & Availability of Puskesmas & 0.00 \\
\hline & & & Availability of Polindes & 1.00 \\
\hline & & & Available of Midwives & 0.00 \\
\hline & & & Availability of Posyandu & 1.00 \\
\hline & & & $\begin{array}{l}\text { Availability of Doctor/Midwife } \\
\text { Certified }\end{array}$ & 0.00 \\
\hline & Health Insurance & 0.00 & BPJS membership level & 0.00 \\
\hline
\end{tabular}

TABLE V. RESULTS FOR EDUCATION DIMENSION

\begin{tabular}{|c|c|c|c|c|}
\hline Dimension Index & Variable & $\begin{array}{l}\text { Variable } \\
\text { Index }\end{array}$ & Indicators & Indicator Index \\
\hline \multirow{5}{*}{0.64} & \multirow{2}{*}{$\begin{array}{l}\text { Level of } \\
\text { Education and } \\
\text { Literacy }\end{array}$} & \multirow[b]{2}{*}{0.52} & Education Level of Villagers & 0 \\
\hline & & & $\begin{array}{l}\text { Level of reading and numeracy } \\
\text { literacy }\end{array}$ & 1 \\
\hline & \multirow{3}{*}{$\begin{array}{l}\text { Education } \\
\text { facilities }\end{array}$} & \multirow{3}{*}{0.76} & $\begin{array}{l}\text { Availability of Learning } \\
\text { Facilities and Infrastructure }\end{array}$ & 1.00 \\
\hline & & & $\begin{array}{ll}\text { Accessability to Schools } \\
\text { Affordable and Easy }\end{array}$ & 1.00 \\
\hline & & & $\begin{array}{l}\text { Availability of Adequate } \\
\text { Teachers }\end{array}$ & 0.25 \\
\hline
\end{tabular}

Education facilities of Mekarwangi Village are good as shown by results of a high indicator index, that is, availability of facilities and learning infrastructure, affordable and easy access to schools, and an adequate number of teachers. Thus, the village received a variable index value of 0.76 , with the final value for the education dimension at 0.64 suggesting that education in Mekarwangi Village is good and less of a priority for assistance
Fourth, the social and human dimension score was derived from results of the variables of public space interaction, communication and information infrastructure, and disaster mitigation. Variables that do not positively affect social and human value improvement are disaster mitigation variables because Mekarwangi Village does not have facilities and infrastructure for disaster mitigation despite its proximity to the Tangkuban Perahu Mount, which is still active (Table VI). 
The $d a$ 'wah dimension's result was 0.8 , indicating that Mekarwangi villagers' religiosity is good. Table IV shows that this value is supported by availability of facilities and religious companions, with a score of 0.92 . The number of religious companions was 13 , and there are 14 mosques and 28 mushalla. The level of religious knowledge of society is at 0.89 because in Mekarwangi Village, every RW has run every week. The collection of zakat in Mekarwangi Village is well organized, with a total of $89.72 \%$ or $\mathrm{Rp}$. $49,991,984.00$, and the level of religious activity and community participation is $70 \%$ of the total population, with a score of 0.63 (Table VII).

TABLE VI. RESULTS FOR INDEX VALUE OF SOCIAL AND HUMANITY DIMENSION

\begin{tabular}{|c|c|c|c|c|}
\hline Dimension Index & Variable & $\begin{array}{l}\text { Variable } \\
\text { Index }\end{array}$ & Indicators & Indicator Index \\
\hline \multirow{7}{*}{0.71} & \multirow{2}{*}{$\begin{array}{l}\text { Public Space } \\
\text { Interaction } \\
\text { Facility }\end{array}$} & \multirow{2}{*}{1} & Availability of Sports Facilities & 1 \\
\hline & & & $\begin{array}{l}\text { Availability of Citizen Activity } \\
\text { Group }\end{array}$ & 1 \\
\hline & \multirow{4}{*}{$\begin{array}{l}\text { Electricity, } \\
\text { Communication, } \\
\text { and Information } \\
\text { Infrastructure }\end{array}$} & \multirow{4}{*}{0.82} & Availability of Electric Flow & 1.00 \\
\hline & & & $\begin{array}{l}\text { Availability of } \\
\text { Communications Access }\end{array}$ & 0.50 \\
\hline & & & Availability of Internet Access & 0.75 \\
\hline & & & $\begin{array}{l}\text { Availability of Television or } \\
\text { Radio Broadcast }\end{array}$ & 1.00 \\
\hline & $\begin{array}{l}\text { Natural Disaster } \\
\text { Mitigation }\end{array}$ & 0.00 & Disaster Management & 0.00 \\
\hline
\end{tabular}

TABLE VII. RESULTS FOR DA’WAH DIMENSION

\begin{tabular}{|c|c|c|c|c|}
\hline $\begin{array}{c}\text { Dimension } \\
\text { Index }\end{array}$ & Variable & $\begin{array}{c}\text { Variable } \\
\text { Index } \\
\end{array}$ & Indicators & Index of Indicators \\
\hline \multirow{8}{*}{0.80} & \multirow{3}{*}{$\begin{array}{l}\text { Avaibility of } \\
\text { religious facilities } \\
\text { and companions }\end{array}$} & \multirow{3}{*}{0.9225} & Availability of mosques & 0.75 \\
\hline & & & Accessibility of the mosque & 1.00 \\
\hline & & & Availability of religious companion & 1.00 \\
\hline & \multirow{2}{*}{$\begin{array}{l}\text { Level of religious } \\
\text { knowledge society }\end{array}$} & \multirow[b]{2}{*}{0.89} & Level of literacy Al-Quran & 0.75 \\
\hline & & & $\begin{array}{l}\text { Public awareness for zakah dan } \\
\text { infiq }\end{array}$ & 1.00 \\
\hline & \multirow{3}{*}{$\begin{array}{l}\text { Level of religious } \\
\text { activities and } \\
\text { community } \\
\text { participation }\end{array}$} & \multirow{3}{*}{0.63} & $\begin{array}{l}\text { Implementation of routine religious } \\
\text { activities }\end{array}$ & 1.00 \\
\hline & & & $\begin{array}{l}\text { Level of community participation } \\
\text { of praying } 5 \text { times in congregation }\end{array}$ & 0.25 \\
\hline & & & $\begin{array}{l}\text { Level of community participation } \\
\text { in routine religious activities }\end{array}$ & 0.75 \\
\hline
\end{tabular}

\section{CONCLUSION AND IMPLICATION}

Based on the results above, Mekarwangi Village's value for the Zakat Village Index is 0.59 , meaning that it can be considered for Rumah Zakat assistance with zakat funds based on community because of its lowest dimensioneconomics (0.32). Thus, the poor West Bandung village of Mekarwangi can be considered for assistance, with the zakat program's priority to be empowering the community's economic development.

\section{ACKNOWLEDGMENT}

We acknowledge this research was funded by the Directorate of Research and Community Engagement, Universitas Indonesia.

\section{REFERENCES}

[1] A.H.M. Sadeq, "Waqf, perpetual charity and poverty alleviation," International Journal of Social Economics, vol. 29, no. 29, pp. 135-151, 2002.

[2] M.K. Hassan and A. Ashraf, "An integrated poverty alleviation model combining zakat, awqaf and microfinance," In Seventh International Conference-The Tawhidic Epistemology: Zakat and Waqf Economy, Bangi, Malaysia, pp. 261-281, 2010.

[3] I.F. Beik, "Analisis peran zakat dalam mengurangi kemiskinan: Studi kasus Dompet Dhuafa Republika." Jurnal Pemikiran dan gagasan, vol. 2, pp. 1-15, 2009. 
[4] I.S. Beik, "Analisis Peran Zakat Dalam Mengurangi Kemiskinan: Studi Kasus Dompet Dhuafa Republika." Jurnal Zakat \& Empowering, vol. 2, pp. 47-55, 2010

[5] I. Febianto and M.A. Arimbi, "The impact of Qardhul Hasan financing using Zakah funds on economic empowerment (Case study of Dompet Dhuafa, West Java, Indonesia)." Asian Business Review vol. 1, pp. 15-20, 2015.

[6] F. Noerwenda and H.D. Mulyaningsih. "New challenges in creating social entrepreneurs based on Sharia," International Proceedings of Economics Development and Research, vol. 73, p. 10, 2014.

[7] I.S. Beik and L.D. Arsyianti, "Measuring zakat impact on poverty and welfare using CIBEST Model," Journal of Islamic Monetary Economics and Finance, vol. 1, pp. 141-160, 2016.
[8] M.S. Nurzaman, "Evaluating the impact of productive based zakat in the perspective of human development index: a comparative analysis." Kyoto Bulletin of Islamic Area Studies, vol. 9, pp. 42-62, 2016.

[9] M. Claase, "Optimizing feasibility studies: Based on a Grounded Theory type comparison of feasibility design research." Bachelor's thesis, University of Twente, 2012.

[10] C. Zawde, Feasibility study: Preparation and analysis. Princeton Commercial Holdings, 2007.

[11] I.S. Beik, S. Nurzaman, and M. Zaenal, Indeks Desa Zakat. Jakarta: BAZNAS Center of Strategic StudiesBooks.

[12] W.G. Cochran, "Sampling techniques-3," 1977. 